\title{
Introduction - From the Maker Movement to the 3D printing era: opportunities and challenges
}

\section{Dinusha Mendis, Mark Lemley and Matthew Rimmer}

\section{INTRODUCTION}

On 23 November 2017 the European Parliament published a Working Document titled Three-Dimensional Printing, a Challenge in the Fields of Intellectual Property Rights and Civil Liability. ${ }^{1}$ The publication went on to state that the European Commission 'has made 3D printing one of the priority areas of technology' ${ }^{2}$ The technology was also referred to in the European Commission's recent reflection paper on 'harnessing globalisation', stating that three-dimensional (3D) printing, among other emerging technologies, 'will revolutionise how we produce, work, move and consume' (emphasis added). ${ }^{3}$ In April 2018 the European Commission demonstrated its commitment to exploring the intellectual property (IP) implications of industrial 3D printing by commissioning research into this area, in a move to shape policy, while in July 2018 the European Parliament adopted a resolution to regulate $3 \mathrm{D}$ printing in the field of intellectual property rights and civil liability. ${ }^{4}$

1 European Parliament (Committee on Legal Affairs), Working Document: Three-Dimensional Printing, a Challenge in the Fields of Intellectual Property Rights and Civil Liability (23 November 2017) at http://www.europarl.europa.eu/ sides/getDoc.do?type=COMPARL\&reference=PE-612.302\&format=PDF\&language $=$ EN\&secondRef $=01$.

2 ibid.

3 European Commission, Reflection Paper on Harnessing Globalisation (10 May 2017), COM (2017) 240 final at http://eur-lex.europa.eu/legal-content/EN/ TXT/?uri=COM\%3A2017\%3A240\%3AFIN.

4 A project exploring the 'Study into the Intellectual Property Implications of the Development of Industrial 3D Printing' was awarded by the European 
In a further publication titled The Next Production Revolution: Implications for Governments and Businesses, it was emphasised that 'longterm thinking is essential' for technologies such as 3D printing. The report went on to say that 'in addition to addressing short-term challenges, leaders in business, education, unions and government must be ready to frame policies' and reflect on 'how policy priorities may need to evolve, in fields as diverse as the IP system, competition and trade policies, and the distributional implications of future production'.5 As such, 3D printing presents various challenges for the legal, ethical, ${ }^{6}$ medical, and health and safety sectors. ${ }^{7}$ Among these various concerns, there is a focus on the impact of $3 \mathrm{D}$ printing on intellectual property rights (IPRs). ${ }^{8}$

The need for imminent change and responsive policy, particularly in the area of IPRs, has been acknowledged and echoed in a number of countries, including the United Kingdom (UK), the United States of America (USA) and Australia - the jurisdictions which are the focus of this book.

This introductory chapter is set out as follows. It commences with a brief outline and history of 3D printing, additive manufacturing and the Maker Movement. It provides a geographical overview of the development and distribution of IP and 3D printing. Thereafter, it moves on to setting out the reasons for selecting the UK, the USA and Australia as a basis for consideration, before providing a brief synopsis of some of the IP challenges addressed in the book. It concludes with an overview of the layout of the book.

Commission in April 2018 to a team of researchers led by Professor Dinusha Mendis of Bournemouth University. On 3 July 2018, an own-initiative report by Joëlle Bergeron titled Three-Dimensional Printing, a Challenge in the Fields of Intellectual Property Rights and Civil Liability was adopted by the European Parliament (2017/2007/(INI)).

5 OECD, The Next Production Revolution: Implications for Governments and Businesses (September 2017) at https://www.keepeek.com//Digital-AssetManagement/oecd/science-and-technology/the-next-production-revolution_97892 64271036-en\#page19 [17].

6 ibid. chapter 5 .

7 European Commission Report (n 3 ) 3.

8 OECD Report (n 5) 57; see also International Trademark Association (INTA), 3D Printing: Key Legal Issues and Options for Change (August 2017). 


\section{A HISTORY OF 3D PRINTING, ADDITIVE MANUFACTURING AND THE MAKER MOVEMENT}

Additive manufacturing, also known as 3D printing, is where objects are created, laying one layer on top of the other, until a 3D object is created. The technology has so far mostly been used for rapid prototyping and rapid tooling but is now being used to manufacture end-use parts. It is transforming the way companies manufacture their products and has the potential to revolutionise global manufacturing. ${ }^{9}$

On an experimental level, 3D printing dates back to the $1960 \mathrm{~s}^{10}$ However, it was in the 1970s that the concept was first described (although it was not called additive manufacturing nor 3D printing) in an article in the New Scientist magazine authored by David Jones, a British chemist. In his article published on 3 October 1974, Jones made a tongue-in-cheek proposal about how the technology could work:

Many liquid monomers can be polymerised to solid by ultraviolet light, or even visible light. Accordingly a laser-beam shone through a tank of monomer should leave an optically straight fibre in its path ... two different laser-beams traversing the tank would then form a solid spot of polymer at their point of intersection. By scanning this point around, any type of solid object at all could be made up: even complex interlocking and re-entrant shapes quite impossible to mould. This effortless optical sculpture would revolutionise the plastic arts in all senses. ${ }^{11}$

The concept which appeared in New Scientist in 1974 was realised three years later, in 1977, when a US patent was granted to Wyn Kelly Swainson for the same idea described by Jones, although Swainson had filed the patent in $1971^{12}$ before Jones's article was published. Although Swainson's patent did not lead to a commercially available 3D printer, it paved the way for practical additive manufacturing of 3D parts under computer control (rapid prototyping) ${ }^{13}$ whilst demonstrating the potential of this technology.

9 United Kingdom, Made Smarter Review 2017 (formerly known as Industrial Digitalisation Review 2017) at http://industrialdigitalisation.org.uk/ 107.

10 European Parliament Report (n 1).

11 David Jones, 'Ariadne' Column (1974) New Scientist 80.

12 Application no. 05/165042 filed 23 July 1971. U.S. Patent 4,041,476 'Method, medium and apparatus for producing three-dimensional figure product' granted 9 August 1977.

13 Adrian Bowyer, 'The Self-Replicating Rapid Prototyper - Manufacturing for the Masses', Keynote Address on the RepRap Project given by Dr Bowyer at 
Ultimately, it was Charles Hull who led the way for the launch of the first commercial additive manufacturing machine in 1988. It was made possible by a US patent granted in March 1986 titled 'Apparatus for Production of Three-Dimensional Objects by Stereolithography'. ${ }^{14}$ Since then, the technology has developed and matured significantly, leading to further commercial development and industrial application. ${ }^{15}$

Whilst industrial application through additive manufacturing continued to thrive during the 1990 s to 2000 s driven forward mainly by 3D systems, ${ }^{16}$ interest in the use of 3D printing in professional settings and personalised home formats also began to gain traction with the setting up of Massachusetts Institute of Technology's (MIT) Center for Bits and Atoms (CBA) in 2001.17 Much like homebrew computer clubs formed around personal computing, the coming-into-being of fab labs ${ }^{18}$ and the social phenomenon of the Maker Movement rose around 3D printing and other emerging technologies. ${ }^{19}$ In 2012, Chris Anderson provided a portrait of this creative community:

What defines the Maker Movement? It's a broad description that encompasses a wide variety of activities, from traditional crafting to high-tech electronics, many of which have been around for ages. But Makers ... are doing

the 7th National Conference on Rapid Design, Prototyping and Manufacturing, June 2006 at http://reprap.org/wiki/PhilosophyPage.

14 Application no. 06/638,905 filed 8 August 1984. U.S. Patent 4,575,330 'Apparatus for Production of Three-Dimensional Objects by Stereolithography' granted 11 March 1986.

15 Terry Wohlers, 'Early Research and Development', Wohlers Report 2005 at http://www.wohlersassociates.com/history.pdf.

16 Hod Lipson and Melba Kurman, Fabricated: The New World of $3 D$ Printing (John Wiley \& Sons Inc. 2013) chapter 2.

17 Neil Gershenfeld, Alan Gershenfeld and Joel Cutcher-Gershenfeld, Designing Reality: How to Survive and Thrive in the Third Digital Revolution (Basic Books 2017) 18-24.

18 ibid. Fab labs (laboratories for fabrication) began as an experiment to see what would happen if the most popular of CBA's tools internally became widely available externally. The first full community fab lab opened in Boston in 2005.

19 Chris Anderson, Makers: The New Industrial Revolution (Random House LLC 2012); Mark Hatch, The Maker Movement Manifesto: Rules for Innovation in the New World of Crafters, Hackers, and Tinkerers (McGraw-Hill Books 2013); Mark Hatch, The Maker Revolution: Building a Future on Creativity and Innovation in an Exponential World (John Wiley \& Sons Inc. 2018); Dale Doughtery with Ariane Conrad, Free to Make: How the Maker Movement is Changing Our Schools, Our Jobs, and Minds (North Atlantic Books 2016); and Peter Hirschberg, Dale Doughtery and Marcia Kadanoff, Maker City: A Practical Guide for Reinventing American Cities (Maker Media 2016). 
something new. First, they're using digital tools, designing onscreen, and increasingly outputting to desktop fabrication machines. Second, they're the Web generation, so they instinctively share their creations online. By sampling bringing the Web's culture and collaboration to the process of making, they're combining to build something on a scale we've never seen from DIY before. ${ }^{20}$

Supported by innovative forms of finance such as crowd funding, the Maker Movement embraced a do-it-yourself ethos: a networked approach to collaboration, and open innovation embracing an aesthetic of 'remix culture' ${ }^{21}$

A number of innovation spaces have supported the Maker Movement including makerspaces, fab labs, techshops and hackerspaces. ${ }^{22}$ Such spaces have some subtle differences as outlined below.

Makerspaces - popularised by Make magazine - are publicly accessible places that enable makers to design and create. ${ }^{23}$ Maker Faires are events created by Make magazine designed to celebrate arts, crafts, engineering and science. In his optimistic text, Dale Doughtery depicts the Maker Movement as a progressive social movement:

The Maker Movement signals a societal, cultural, and technological transformation that invites us to participate as producers, not just consumers. It is changing how we learn, work, and innovate. It is open and collaborative, creative and inventive, hands-on and playful. We don't have to conform to the present reality or accept the status quo - we can imagine a better future and realize that we are free to make it. ${ }^{24}$

20 Chris Anderson, Makers: The New Industrial Revolution (Random House LLC 2012) 20-21.

21 Henry Jenkins, Convergence Culture: Where Old and New Media Collide (New York University Press 2006); Yochai Benkler, The Wealth of Networks: How Social Production Transforms Markets and Freedom (Yale University Press 2007); Lawrence Lessig, Remix: Making Art and Commerce Thrive in the Hybrid Economy (Penguin Press 2008); Eva Hemmungs Wirtén and Maria Ryman (eds), Mashing-Up Culture: The Rise of User-Generated Content (Uppsala University 2009); Ediardo Navas, Owen Gallagher and Xtine Burrough, Keywords in Remix Studies (Routledge 2018).

22 Gui Cavalcanti, 'Is It A Hackerspace, Makerspace, TechShop, or FabLab?', Make (22 May 2013) at https://makezine.com/2013/05/22/the-differencebetween-hackerspaces-makerspaces-techshops-and-fablabs/.

23 Dale Doughtery with Ariane Conrad, Free to Make: How the Maker Movement is Changing Our Schools, Our Jobs, and Minds (North Atlantic Books 2016).

24 ibid. xxi. 
Together with Peter Hirshberg and Marcia Kadanoff, Dale Doughtery has also written about the role of 3D printing and the Maker Movement in reinventing American cities. ${ }^{25}$ This book contends that an open innovation ethos can be helpful in promoting urban renewal and open innovation. ${ }^{26}$

In 2005 Neil Gershenfeld considered the emergence of fabspaces. ${ }^{27} \mathrm{He}$ predicted: 'Personal fabrication will bring the programming of the digital worlds we've invented to the physical world we inhabit.' ${ }^{28}$ Since Gershenfeld's 2005 prediction, there has been a significant interest in the use of $3 \mathrm{D}$ printing in the creative arts, education, manufacturing, health-care and sustainability, ${ }^{29}$ leading to a larger economic discussion as to whether 3D printing is part of a new industrial revolution. ${ }^{30}$

TechShop provided a chain of membership-based workshops and studios. Its former lead Mark Hatch has written manifestos on the development of distributed and flexible manufacturing and the acceleration of innovation. ${ }^{31}$ However, the US company TechShop declared bankruptcy in 2018. There have since been trade mark conflicts over the name TechShop - after Dan Rasure tried to establish a new version of the entity. ${ }^{32}$

The European concept of a hackerspace refers to a collection of programmers sharing a physical space. As the notion of hacking has

25 Hirschberg, Doughtery and Kadanoff (n 19).

26 ibid. 13

27 Neil Gershenfeld, Fab: The Coming Revolution of Your Desktop - From Personal Computers to Personal Fabrication (Basic Books 2005).

28 ibid. [17].

29 Hod Lipson and Melba Kurman, Fabricated: The New World of $3 D$ Printing (John Wiley \& Sons Inc. 2013). See also John Hornick, 3D Printing Will Rock the World (CreateSpace Independent Publishing 2015).

30 Christopher Winnan, 3D Printing: The Next Technology Gold Rush (CreateSpace Independent Publishing 2012); Jeremy Rifkin, The Zero Marginal Cost Society: The Internet of Things, the Collaborative Commons, and the Eclipse of Capitalism (St Martin's Press 2014); John Hornick, 3D Printing Will Rock the World (CreateSpace 2015); Klaus Schwab, The Fourth Industrial Revolution (Crown Business 2016); Thomas Birtchnell and John Urry, A New Industrial Future? 3D Printing and the Reconfiguring of Production, Distribution, and Consumption (Routledge 2016).

31 Hatch, The Maker Movement Manifesto (n 19); and Hatch, The Maker Revolution (n 19).

32 TechShop Inc. v Dan Rasure (2018) Case 4:18-cb-0144-DMR. 
expanded, the realm of a hackerspace has been enlarged to include $3 \mathrm{D}$ printing and additive manufacturing technologies. ${ }^{33}$

In terms of its relevance for IP laws, it can be argued that the emergence of these innovative spaces leading to 3D printing has given rise to complex issues due to the fact that it touches on all aspects of IP law and also has political, philosophical, social and legal implications. ${ }^{34}$ Notwithstanding this history, the advent of 3D printing was not perceived to be significant in terms of IP law until recently. ${ }^{35}$ This may have been because $3 \mathrm{D}$ printing has until recently been used mainly for the specialist purpose of rapid prototyping, with limited access to the public. As a result, and prior to the expiration of Charles Hull's patent in 2008, the issues associated with consumer IP rights were seen as being more academic than of practical importance. ${ }^{36}$ More recently, however, the use of $3 \mathrm{D}$ printing by the public has greatly expanded and diversified, and low-cost 3D printers have become available to the average consumer. ${ }^{37,38}$ Moreover, the widespread use of the Internet has made the technology more accessible by facilitating not only communication of knowledge, but also dissemination of designs for 3D printing, often referred to as Computer-Aided Design (CAD) files. ${ }^{39}$ With these recent changes in the surrounding circumstances of 3D printing, it seems that its impact upon IP law has become not only significant, but also challenging.

33 Cavalcanti (n 22).

34 Bibi van den Berg, Simone van der Hof and Eleni Kosta (eds), 3D Printing: Legal, Philosophical and Economic Dimensions (TMC Asser Press 2016).

35 Dinusha Mendis, “The Clone Wars": Episode 1 - The Rise of 3D Printing and its Implications for Intellectual Property Law - Learning Lessons from the Past?' [2013] European Intellectual Property Review 155.

36 ibid. See also UK Intellectual Property Office, 3D Printing: A Patent Overview (November 2013) at https://www.gov.uk/government/uploads/system/ uploads/attachment_data/file/445232/3D_Printing_Report.pdf.

37 Wei Gao and others, 'The Status, Challenges, and Future of Additive Manufacturing in Engineering' (2015) 69 Computer-Aided Design 65.

38 For a list of expired core patents of 3D printing, see Stefan Bechtold, '3D Printing, Intellectual Property and Innovation Policy' [2016] International Review of Intellectual Property and Competition Law 517, 532.

39 Mendis (n 35). 


\section{A GEOGRAPHY OF INTELLECTUAL PROPERTY AND 3D PRINTING}

Since 2010 there has been a hive of ongoing activity in relation to $3 \mathrm{D}$ printing and additive manufacturing technologies. At the helm of this activity are the UK, the USA and Australia, together with countries such as Germany, Japan, China and South Korea. ${ }^{40}$ However, this book focuses on three jurisdictions in particular - those of the UK, the USA and Australia. The reasons for this focus can be summarised into three broad points:

(1) The three selected countries are actively involved in developing 3D printing and additive manufacturing technologies whilst positioning themselves as world leaders.

(2) Importantly, and of much relevance to this book, all three countries have been at the forefront of progressive IP policy reform and addressing issues relating to this technology, whether this be in the form of government-commissioned projects leading to policy intervention or through academic scholarship emanating from specialists leading the way in IP law. As such, the three selected jurisdictions have contributed significantly to addressing the IP challenges generated by $3 \mathrm{D}$ printing and additive manufacturing technologies, which this book captures in detail.

(3) Related to the second point is also the fact that the three selected jurisdictions share a common law tradition. Recent case law drawn from the UK, the USA and Australia have begun to inform IPRs surrounding $3 \mathrm{D}$ printing and additive manufacturing. Therefore, through a consideration of three common law jurisdictions representing three continents, this book aims to provide a holistic insight into the IP implications of 3D printing and additive manufacturing.

40 Ernst \& Young, How Will 3D Printing Make Your Company the Strongest Link in the Value Chain? (2016) at http://www.ey.com/Publication/vwLUAssets/ ey-global-3d-printing-report-2016-full-report/\$FILE/ey-global-3d-printing-report2016-full-report.pdf. 


\subsection{Market Leaders in 3D Printing and Additive Manufacturing Technologies}

\subsubsection{United Kingdom}

The UK is among the world's leaders in research, innovation and adoption of additive manufacturing technology for high-performance applications in medicine, aerospace and other industry sectors ${ }^{41}$ comprising a relatively small but solid foundation of companies applying this technology within product development activities for prototyping and tooling.

The country has a world-class additive manufacturing capability, well-established national centres (The Manufacturing Technology Centre) and university excellence ${ }^{42}$ in terms of research. Four universities, in particular, lead the way internationally in this area, namely, Loughborough University, Nottingham University, the University of Birmingham and the University of Cambridge. Each of these universities has research centres dedicated to the development of additive manufacturing and 3D printing and through government funding has involved other universities, thereby widening participation. For example, the government-funded Centre for Doctoral Studies in Additive Manufacturing is led by Nottingham University in partnership with Loughborough University, Newcastle University and the University of Liverpool. It is further backed by Nottingham University's Centre for Additive Manufacturing.

The University of Cambridge's government-funded Institute for Manufacturing (IfM) is a world-leading research centre which aims to help companies develop life-changing products and services, build better businesses, create meaningful jobs and improve the environment for the future. The research centre is also dedicated to helping the UK government foster innovation and enterprise to deliver social and economic benefits. ${ }^{43}$

Addressing the rise of additive manufacturing and 3D printing technologies, the UK government pledged $£ 7$ million in 2012 for research

$41 \quad$ Made Smarter Review 2017 (n 9) 63.

42 The Manufacturing Technology Centre, Coventry at http://www.themtc.org/; Nottingham University's Centre for Additive Manufacturing at https:// www.nottingham.ac.uk/research/groups/cfam/; Cambridge University's Institute for Manufacturing at https://www.ifm.eng.cam.ac.uk/aboutifm/; University of Birmingham's Advanced Manufacturing Technology Centre at https://www. birmingham.ac.uk/research/activity/mechanical-engineering/advanced-manufacturing/ index.aspx.

43 University of Cambridge, Institute for Manufacturing at https://www.ifm. eng.cam.ac.uk/aboutifm/. 
and development, universities and science. ${ }^{44}$ This was increased to a government grant of over $£ 60$ million in 2013-2014. ${ }^{45}$ Since then, the UK has led the way in the medical, aerospace, automotive and consumer markets (including, in particular, fashion and electronics). ${ }^{46}$

Responding to the UK government's initiatives, in March 2015 a steering group of senior representatives of a range of public and private sector organisations produced an 'Additive Manufacturing Strategy Positioning Paper' that provided an overview of the importance of additive manufacturing and $3 \mathrm{D}$ printing to the UK economy. ${ }^{47}$ This Positioning Paper marked the starting point for the development of the UK National Strategy for Additive Manufacturing and 3D Printing, which is dedicated to exploring all aspects of the additive manufacturing and 3DP process, including (i) materials and processes; (ii) design; (iii) skills; (iv) standards and certification; (v) test and validation; (vi) IP and security; and (vii) cost and finance. ${ }^{48}$

More recently, in 2017 the UK government published the Industrial Strategy Green Paper, answering the call of government to set out a vision for growth and increased productivity across the manufacturing sector by unlocking the potential of industrial digital technologies (IDTs). ${ }^{49}$ In October 2017 the Made Smarter Review 2017 suggested that the UK's manufacturing sector could unlock $£ 445$ billion over the next decade and create thousands of jobs 'if it cracks the fourth industrial revolution'; it could also put Britain at the forefront of new technologies such as 3D printing and 3D scanning, among others, giving a muchneeded productivity boost and a net gain of 175,000 highly skilled, better-paid jobs. ${ }^{50}$

44 Additive Manufacturing Platform, Additive Manufacturing: Strategic Research Agenda (2014) 13.

45 Department for Business, Innovation and Skills, ' $£ 67$ million to support British innovators' (5 November 2014) at https://www.gov.uk/government/news/ 67-million-to-support-british-innovators. See also OECD Report (n 5) 202.

46 Additive Manufacturing Platform (n 44) 27-31.

47 UK National Strategy for Additive Manufacturing, Positioning Paper: The Case for Additive Manufacturing (March 2015) at http://www.amnational strategy.uk/wp-content/uploads/2015/05/AM-Strategy-Positioning-Paper.pdf. See also, http://www.amnationalstrategy.uk/.

48 UK National Strategy for Additive Manufacturing, What Did the Initial Evidence Reveal? (Update Report 2), October 2015 at http://www.amnational strategy.uk/wp-content/uploads/2015/05/UK-AM-National-Strategy-Update-Report2.2.pdf.

49 Made Smarter Review 2017 (n 9).

50 ibid. [8]. 
The report goes on to say that 'by 2030, the UK will be a global industrial leader in creating, adopting and exporting advanced digital technologies, shaping how the world does business'. ${ }^{51}$ In the short term, industry is expected to invest $£ 600$ million over the next five years, and spend more than $£ 30$ million on additive manufacturing-related research. ${ }^{52}$

Whilst research into additive manufacturing and 3D printing has been progressing rapidly, the UK Intellectual Property Office (UKIPO) has also shown its commitment in relation to the IP implications of 3D printing. To date, the UKIPO has commissioned two studies in this area and is dedicated to shaping policy in the context of IP and 3D printing. ${ }^{53}$

However, the position of the UK will be complicated by its withdrawal from the European Union as part of Brexit. There has been significant discussion about how the UK's IP regime and regulatory system will be affected by Brexit. ${ }^{54}$

\subsubsection{United States of America}

In response to concerns about the retreat of American manufacturing there has been an investment in advanced manufacturing and new technologies such as 3D printing, robotics, information technology, and automation. ${ }^{55}$

The USA is a world leader in $3 \mathrm{D}$ printing and additive manufacturing. A majority of the world's leading specialist additive manufacturing companies are based in the USA - such as Stratasys, 3D Systems, Desktop Metal, Organovo, Formlabs, Shapeways and Made in Space. There have also been a large number of American start-ups focused on 3D printing. ${ }^{56}$

51 ibid. [7].

52 ibid. [64].

53 See nn 138 and 139.

54 Graeme Dinwoodie and Rochelle Cooper Dreyfuss, 'Brexit and IP: The Great Unraveling' (2018) 39 Cardozo Law Review 967-994; Alexandra George, 'Just Keep Calm and Carry On: The Impact of Brexit on Intellectual Property Laws in Britain and the European Union' (2017) 1(1) Journal of Intellectual Property Studies 90-130; and Oonagh Fitzgerald and Eva Lein (eds), Complexity's Embrace: The International Law Implications of Brexit (McGill-Queen's University Press 2018); United Kingdom Government, 'IP and Brexit: The Facts', at https://www.gov.uk/government/news/ip-and-brexit-the-facts.

55 Vaclav Smil, The Rise and Retreat of American Manufacturing (MIT Press 2015).

56 Jan-Peter Ferdinand, Entrepreneurship in Innovation Communities: Insights from 3D Printing Startups and the Dilemma of Open Source Hardware (Springer 2017). 
Moreover, the USA hosts a range of technology companies, which have developed significant expertise in 3D printing - such as GE, HP and Boeing.

The United States Congress has taken a deep interest in 3D printing and additive manufacturing. After Public Knowledge held a number of 3D/DC events, ${ }^{57}$ the United States Congress established a Congressional Maker Caucus in 2014.58 The Congressional Maker Caucus "works to support and advocate for the community of makers who use technologies such as 3D printers, Computer Numerical Control (CNC) machines, laser cutting machines and other manufacturing technologies that enable anyone from individuals to small and large companies to create new products'. ${ }^{59}$ The Congressional Maker Caucus has supported initiatives such as legislative bills to promote 'maker' education. ${ }^{60}$ US Congressional committees have also considered legal and regulatory issues associated with disruptive technologies, such as 3D printing. ${ }^{61}$

Hosting a White House Maker Faire in 2014, President Obama emphasised that 3D printing could play a key role in education, training, employment and innovation. ${ }^{62} \mathrm{He}$ highlighted the role of $3 \mathrm{D}$ printing in

57 Public Knowledge, '3D/DC: 3D Printing Comes to the Nation's Capital' (April 2011) https://www.publicknowledge.org/events/3d-dc-3d-printing-comesto-the-nations-capital-2011.

58 Michael Molitch-Hou, '3D Printing Has Fans on Capitol Hill with the Congressional Maker Caucus', 3D Printing Industry (28 February 2014) at https://3dprintingindustry.com/news/3d-printing-fans-capitol-hill-congressionalmaker-caucus-24396/.

59 Rep. Mark Takano, 'Committees and Caucuses' at https://takano. house.gov/about/committees-and-caucuses.

60 Lisa Bielmeier, "Gillibrand Introduces Bill to Promote "Maker" Education', Lockport Union-Sun \& Journal (27 November 2017) at http://www. lockportjournal.com/news/local_news/gillibrand-introduces-bill-to-promote-makereducation/article_2d2693dc-61b5-537e-9921-42241492af3c.html. 21st Century Strengthening On Programs that Cultivate Learning Approaches for Successful Students Act at https://www.gillibrand.senate.gov/imo/media/doc/21st\%20 Century\%20SHOP\%20CLASS\%20Act.pdf.

61 United States House of Representatives Committee on Energy and Commerce, The Disrupter Series: 3D Printing (United States Government Publishing Office Washington 2016) at https://energycommerce.house.gov/ hearings/disrupter-series-3d-printing/.

62 President Barack Obama, 'Remarks by the President at the White House Maker Faire', White House (18 June 2014) at https://obamawhitehouse. archives.gov/the-press-office/2014/06/18/remarks-president-white-house-makerfaire. 
democratising American manufacturing, innovation and entrepreneurship. President Obama vowed:

We're going to rebuild our economy and restore our middle class, and give opportunities for people whose potential is not yet tapped. There are kids out there, there are adults out there right now who have a great idea. And they don't have access to the capital they need. They don't have the tools they need to put together a prototype. They don't know how to link up with folks who could help refine those ideas. And what the Maker movement does, what technology does, what the information revolution does is it allows all those folks to suddenly be a part of this creative process. And what better place to do that than here in the United States of America? This is a place where we know how to invent and we know how to dream and we know how to take risks. ${ }^{63}$

President Obama said, 'I hope every company, every college, every community, every citizen joins us as we lift up makers and builders and doers across the country.' 64

A few years ago, the US federal government renewed funding for advanced manufacturing to ensure that the $3 \mathrm{D}$ printing industry achieves its potential and benefits the US economy. ${ }^{65}$ Initially, a 2011 White House Advanced Manufacturing Report called for new commitment by the administration to manufacturing, as a long-term structural approach rather than a short-term economic stimulus. ${ }^{66}$ This aim was renewed in 2012 and 2013 by the establishment of a number of manufacturing institutes, backed by President Obama. In 2014 he pledged ' 11 agencies that collectively grant over USD 2.5 billion annually to small businesses across the country ... are committing to leverage the programs to support maker innovations' ${ }^{67}$

This vision has been represented through the government-backed initiatives of Manufacturing USA, which also includes America Makes as

63 ibid.

64 ibid.

65 See also William Bonvillian, 'The Rise of Advanced Manufacturing Institutes in the United States' in OECD, The Next Production Revolution: Implications for Governments and Businesses (September 2017) at https:// www.keepeek.com//Digital-Asset-Management/oecd/science-and-technology/thenext-production-revolution_9789264271036-en\#page, chapter 11.

66 President's Council of Advisors on Science and Technology, Report to the President on Ensuring American Leadership in Advanced Manufacturing (June 2011) at https://obamawhitehouse.archives.gov/sites/default/files/microsites/ostp/ pcast-advanced-manufacturing-june2011.pdf.

67 OECD Report (n 5) 202. 
one of its 14 institutes. Manufacturing USA, or the National Network for Manufacturing Innovation programme, was formally established in 2014 and, through its established institutes, works towards a common goal: to secure the future of manufacturing in the USA through innovation, education and collaboration. ${ }^{68}$

William Bonvillian and Peter Singer have provided an analysis of the Advanced Manufacturing Institute model developed under President Obama. ${ }^{69}$ Bonvillian and Singer highlight the consortium approach taken in the development of the America Makes programme, bringing together governments, universities and colleges, and industry. ${ }^{70}$ They observed that the Institute has worked to 'create an infrastructure for the sharing of additive manufacturing ideas and research on development and evaluation of additive manufacturing technologies, on linking small and midsize firms with resources to enable them to use additive manufacturing' ${ }^{71}$ Bonvillian and Singer acknowledge that the IP issues have been complicated:

While information and IP sharing among the highly competitive larger aerospace firms proved complex, which has affected technology development, the institute has played a significant role in convening the new 3D printing community, helping participants learn which researchers and firms are working on such advances, thereby promoting connections and contracting. ${ }^{72}$

Whilst the USA is well supported by the government and has a number of well-established additive manufacturing facilities and institutes as outlined above, it also has over 30 universities and colleges engaged in excellence in the development of 3D printing and additive manufacturing technologies, which demonstrates its desire for continued excellence in this field. ${ }^{73}$

The new US President Donald Trump campaigned on restoring manufacturing jobs to the USA. There has been much discussion about the public policy options of the Trump administration with regard to manufacturing. ${ }^{74}$

68 Manufacturing USA, 'Program Details', https://www.manufacturingusa. com/pages/program-details.

69 William Bonvillian and Peter Singer, Advanced Manufacturing: The New American Innovation Policies (MIT Press 2017).

70 ibid. 140-142.

71 ibid. 143.

72 ibid. 143.

73 America Makes Membership at https://www.americamakes.us/member ship/current-members/.

74 Jack Karsten, 'Trump Administration Brings a Different Approach to Manufacturing', Brookings (14 July 2017) at https://www.brookings.edu/ 
Pursuing an 'America First' trade policy, the Trump administration has brought trade action against China because of concerns about IP infringement. ${ }^{75}$ The Trump administration is concerned about the "Made in China $2025^{\prime}$ industrial development policy, which targets emerging technologies, including 3D printing, robotics, artificial intelligence and biotechnology. ${ }^{76}$

\subsubsection{Australia}

In Australia the federal Australian government has been pursuing a National Innovation and Science Agenda - nicknamed the 'Ideas Boom'. ${ }^{77}$ Australia is also one of the first countries to commit heavily to 3D printing and additive manufacturing technologies, with a significant collaboration being formed in 2010 between Amaero Manufacturing and Monash University's Centre for Additive Manufacturing, which continues to date. ${ }^{78}$ Since then, Australia has moved forward rapidly in this field. The Australian government, via the Australian Research Council, has also dedicated funding of $\$ 25$ million over seven years to the Australian Centre of Excellence for Electromaterials Science (ACES), which incorporates six collaborating Australian universities and five international partner collaborators. ${ }^{79}$ ACES has links to a considerable number of other international organisations. Led by the University of Wollongong, ACES' remit is to translate the

blog/techtank/2017/07/14/trump-administration-brings-a-different-approach-tomanufacturing/.

75 Office of the United States Trade Representative, 'President Trump Announces Strong Actions to Address China's Unfair Trade', Press Release (March 2018) at https://ustr.gov/about-us/policy-offices/press-office/pressreleases/2018/march/president-trump-announces-strong. See also United States Trade Representative, 'Findings of the Investigation into China's Acts, Policies, and Practices Related to Technology Transfer, Intellectual Property, and Innovation under Section 301 of the Trade Act of 1974' (22 March 2018) at https:// ustr.gov/sites/default/files/Section\%20301\%20FINAL.PDF.

76 Jason Fang and Michael Walsh, 'Made in China 2025: Beijing's Manufacturing Blueprint and Why the World is Concerned', ABC News (29 April 2018) at http://www.abc.net.au/news/2018-04-29/why-is-made-in-china-2025making-people-angry/9702374.

77 The National Innovation and Science Agenda, 'Welcome to the Ideas Boom' (7 December 2015) at https://www.innovation.gov.au/page/nationalinnovation-and-science-agenda-report.

78 Monash Centre for Additive Manufacturing at https://platforms.monash. edu/mcam/. See also, Amaero Additive Manufacturing at http://www.amaero. com.au/about/.

79 Australian Centre of Excellence for Electromaterials Science, http://www. electromaterials.edu.au/about/. 
strong performance of Australian materials' scientists into products, whilst examining the ethical implications of additive manufacturing products. ${ }^{80}$

In 2015 Australia's Department of Industry, Innovation and Science showed further commitment to developing 3D printing and additive manufacturing technologies by launching a \$6 million CSIRO Lab 22 Innovation Centre, in order to 'provide Australian companies with access to $3 \mathrm{D}$ printing technologies, promising increased efficiency and productivity gains for the nation's manufacturing needs'. ${ }^{81}$ More recently, in July 2017 the Innovative Manufacturing Cooperative Research Centre (IMCRC) was launched, with the aim of spurring the transformation of the Australian manufacturing industry. ${ }^{82}$ The IMCRC will operate until mid-2022 with up to $\$ 30$ million in funding available to co-fund industry-led research projects. ${ }^{83}$ In this context, the research facility has partnered successfully with ten Australian universities to develop and progress $3 \mathrm{D}$ printing and additive manufacturing technologies, thereby also demonstrating Australia's desire for continued excellence in this field, similar to that of the UK and USA. ${ }^{84}$

In response to the decline of manufacturing industries (particularly in respect of the automobile factories), the States of Victoria and South Australia have invested in 3D printing and advanced manufacturing, with the Victorian government providing \$2 million to develop an additive manufacturing hub to benefit small-to-medium enterprises. ${ }^{85}$ The funding injected by the Victorian government led to the setting up of the

80 Australian Centre of Excellence for Electromaterials Science, http://www. electromaterials.edu.au/mission-statement/.

81 Department of Industry, Innovation and Science, 3D Printing Brings New Dimension to Australian Manufacturing (19 November 2015) at http:// minister.industry.gov.au/ministers/pyne/media-releases/3d-printing-brings-newdimension-australian-manufacturing.

82 Innovative Manufacturing Cooperative Research Centre at http://imcrc. org/about/.

83 Innovative Manufacturing Cooperative Research Centre, Helping Catalyse the Transformation of Australian Manufacturing (July 2017) at http://imcrc.org/ wp-content/uploads/2017/11/IMCRC-fact-sheet_Nov17.pdf.

84 See http://imcrc.org/about/ for information on partnerships with academic institutions in Australia. For instance, in July 2017 Charles Darwin University developed a new metal 3D printer, surpassing any existing metal 3D printing technology. See Lucy Marks, 'World-first Type of 3D Printer could put Northern Territory at "Frontier" of Manufacturing' (18 July 2017) at http://www.abc. net.au/news/2017-07-17/nt-on-map-with-new-3d-printer/8716814.

85 The Hon. Wade Noonan MP, 'Victorian Manufacturing Blasts into a New Era', Press Release, Victoria State Government (11 September 2017) at https:// www.premier.vic.gov.au/victorian-manufacturing-blasts-into-a-new-era/. 
successful NextAero company and its Aerospike Rocket Engine project. ${ }^{86}$ In addition, a number of technology universities based in Victoria have been experimenting with industrial applications of $3 \mathrm{D}$ printing. The Swinburne University of Technology has set up an automated 3D printed repair service for cars. ${ }^{87}$ RMIT's advanced manufacturing precinct has been deploying 3D printing in engineering, health-care and other fields. ${ }^{88}$

In December 2017 the government of South Australia pledged a grant of \$1.4 million to the University of Adelaide to establish the Additive Manufacturing Applied Research Network. ${ }^{89}$ The new facility, supported by IMCRC, will enable many advanced manufacturing projects in defence, medical devices, dental prostheses and injection moulding to be undertaken in Adelaide, marking a significant commitment by Australia to drive the technology forward whilst positioning itself as a market leader. ${ }^{90}$

Under the leadership of Australian Labour Party Premier Annastacia Palaszczuk, the Queensland government has developed an Advanced Manufacturing 10-Year Roadmap and Action Plan, and a Made in Queensland policy. ${ }^{91}$ The Queensland government has highlighted the role of 3D printing in its plans for additive manufacturing: 'Its aspiration for the advanced manufacturing sector is that by 2026 the sector will comprise internationally competitive businesses that build on potentially disruptive technologies that include advanced materials, advanced automation, 3D printing, artificial intelligence, sensors and embedded

86 ibid.

87 Beau Jackson, 'Swinburne Kick-Starts \$1.2 Million Automatic 3D printed Car Repair Service', 3D Printing Industry (14 February 2018) at https://3d printingindustry.com/news/swinburne-kick-starts-1-2-million-automatic-3d-printedcar-repair-service-128914/.

88 RMIT University, 'Advanced Manufacturing Precinct' at https://www. rmit.edu.au/about/our-locations-and-facilities/facilities/research-facilities/advanced -manufacturing-precinct.

89 Priyankar Bhunia, 'Applied Research Network for 3D Printing Being Established in Adelaide', OpenGovAsia (14 December 2017) at https://www.open govasia.com/articles/applied-research-network-for-3d-printing-being-establishedin-adelaide.

90 ibid.

91 Queensland Government, Queensland Advanced Manufacturing 10-Year Roadmap and Action Plan - Powering the Queensland Economy (The Department of State Development, Queensland Government, December 2016) at http:// statedevelopment.qld.gov.au/resources/plan/advanced-manufacturing/advancedmanufacturing-roadmap.pdf; and Queensland Government, 'Made in Queensland', 8 January 2018 at http://statedevelopment.qld.gov.au/industry-development/ made-in-queensland.html. 
electronics to produce customised products.' 92 At the BrisMakerFest in 2017, the State Development Minister Anthony Lynham announced a $\$ 450,000$ grant programme in 2017 to support makerspaces, fab labs and hackerspaces. ${ }^{93}$ He commented: 'Our manufacturers can go to hackerspaces to solve problems, source potential talent and increasingly involve the community in the high-tech world of advanced manufacturing.' ${ }^{94}$ In Queensland there has been significant work by hospitals and universities in respect of bioprinting and other health and biomedical applications of 3D printing. 95

Australia's Productivity Commission has expressed concerns as to whether Australia's innovation policy is coherent and well co-ordinated. ${ }^{96}$ The Productivity Commission noted: 'Australian governments have also invested in maker spaces, incubators, and accelerators with the hope of attracting entrepreneurs and building critical mass to attract skills and investors.' 97 Nonetheless, despite such initiatives, the Productivity Commission was concerned that Australia's performance was still uneven: 'Australia is assessed as having good innovation infrastructure, publicsector organisations and human capital by international standards. Despite these strengths, Australia does not perform as well in terms of commercialising its ideas and innovations and in terms of diffusion as other countries.'98 Among other things, the Productivity Commission has

92 Queensland Government, Queensland Advanced Manufacturing 10-Year Roadmap and Action Plan (n 91).

93 Felicity Caldwell, 'Tech Tinkerers Across Queensland To Get Half a Million Dollars to Set Up Hackerspaces', The Brisbane Times, 2 July 2017 at https://www.brisbanetimes.com.au/national/queensland/tech-tinkerers-acrossqueensland-to-get-half-a-million-dollars-to-set-up-hackerspaces-20170602-gwj53 m.html; and The Edge, The State Library of Queensland, BrisMakerFest, Brisbane, 3 June 2017 at http://edgeqld.org.au/whats-on/brismakerfest/.

94 ibid.

95 The Hon. Cameron Dick, 'Ground-breaking Surgery Another World First for Queensland Health', Press Release, Queensland Government, 8 September 2017 at http://statements.qld.gov.au/Statement/2017/9/8/groundbreaking-surgeryanother-world-first-for-queensland-health; and Beau Jackson, '3D Printed Tibia Saves Man's Leg from Amputation in Brisbane', 3D Printing Industry, 8 September 2017 at https://3dprintingindustry.com/news/3d-printed-tibia-savesmans-leg-amputation-brisbane-120987/.

96 Productivity Commission, An Overview of Innovation Policy, Shifting the Dial: 5 Year Productivity Review, Supporting Paper No. 12 (Productivity Commission 2017) at http://www.pc.gov.au/inquiries/completed/productivityreview/report/productivity-review-supporting12.pdf.

97 ibid. [1].

98 ibid. [24]. 
stressed the need for the Australian government to modernise its IP laws to improve its performance in terms of innovation policy. ${ }^{99}$ There remain concerns about whether Australia is reaching its ambition of becoming an innovative economy. ${ }^{100}$

\subsection{Other Countries as Market Leaders?}

Clearly there are a number of other countries that are either currently well positioned or are in the process of positioning themselves as world leaders in 3D printing technology. Among the most notable in Europe is Germany, ${ }^{101}$ with Scandinavian countries such as Sweden and Finland also making significant investments in the field. ${ }^{102}$ For example, additive manufacturing has a dedicated chapter within the German Bundestag titled 'Report on research, innovation and technological performance Germany 2015 '.103 Furthermore, within the broad context of hightechnology manufacturing, the German government has identified 'Industrie 4.0' (Industry 4.0 (I40)) as a national strategic initiative which is supported through the Ministry of Education and Research (BMBF) and the Ministry for Economic Affairs and Energy (BMWI). ${ }^{104}$ The scheme, launched in 2011, has a 10-15-year plan for I40 based on the government's High-Tech 2020 Strategy. In particular, the initiative aims to

99 Productivity Commission, Intellectual Property Arrangements, Melbourne: Productivity Commission, Report No. 78 (2016) at http://www.pc.gov.au/ inquiries/completed/intellectual-property/report; and Karen Chester, 'What is Fair?', Productivity Commission, Speech, Canberra, 24 February 2017 at http:// www.pc.gov.au/news-media/speeches/fair.

100 Emma Alberici, 'Are We Any Closer to Becoming An Innovative Economy?', RN Breakfast, ABC News (7 May 2018) at http://www.abc.net.au/ radionational/programs/breakfast/are-we-any-closer-to-becoming-an-innovativeeconomy/9734036.

101 World Intellectual Property Organization, World IP Report: Breakthrough Innovation and Economic Growth (World Intellectual Property Organization 2015) at http://www.wipo.int/edocs/pubdocs/en/wipo_pub_944_2015.pdf.

102 Babak Kianian, Sam Tavassoli and Tobias Larsson, 'The Role of Additive Manufacturing Technology in Job Creation: An Exploratory Case Study of Suppliers of Additive Manufacturing in Sweden' (2015) 26 Procedia CIRP 93-98; and Rosa Ballardini, Marcus Norrgard and Jouni Partanen, 3D Printing, Intellectual Property and Innovation: Insights from Law and Technology (Wolters/Kluwer 2017).

103 Bundestag, http://dip21.bundestag.de/dip21/btd/18/043/1804310.pdf.

104 European Commission Digital Transformation Monitor, Germany: Industrie 4.0 (January 2017) at https://ec.europa.eu/growth/tools-databases/dem/ monitor/sites/default/files/DTM_Industrie\%204.0.pdf. 
'drive digital manufacturing forward by increasing digitisation and the interconnection of products, value chains and business models'. ${ }^{105}$

Outside Europe, Japan, China and South Korea are notable for the developments and investments in additive manufacturing and 3D printing.

A 2016 report by Ernst \& Young established that 'Chinese and South Korean companies are the most proactive in applying the technology to end-use production. One in every two expect to use additive manufacturing to make products by 2021.' ${ }^{106}$ In China, this ambition is driven partly by their desire to maintain the country's position as 'global manufacturing leader in the face of rising labor costs' ${ }^{107}$ For example, China has invested CNY 1.5 billion (US\$245 million) in the development of $3 \mathrm{D}$ printing technologies over the next seven years. ${ }^{108}$ The governments of both countries have invested heavily in the technology's development and have positioned themselves as leading 3D printing nations, seeing it as an opportunity to win a competitive advantage. ${ }^{109}$

In 2014 Japan announced that it had allocated CNY 4 billion (US\$38.6 million) in funding for various national 3D printing projects. ${ }^{110}$ Around the same time, the Japanese Ministry of Economy, Trade and Industry launched a new research and development initiative, together with three major universities and institutes and 27 Japanese companies including Mitsubishi, Nissan, and Panasonic, to promote the research and development of 3D metal printers. ${ }^{111}$ Since then, Japan has continued to progress forward. In 2015 Japan set out its long-term goal to build the most advanced industrial 3D printer by 2020 and thereby make a major impact on the global 3D printing market. In view of this, Japan released its 3D Printing Forecast for 2017-2021, thereby firmly positioning itself as a market leader. ${ }^{112}$

105 ibid. [3].

106 Ernst \& Young Report (n 40) 11.

107 ibid. See also Qian Dai, 'China and the Next Production Revolution' in OECD, The Next Production Revolution: Implications for Governments and Businesses (September 2017) at https://www.keepeek.com//Digital-AssetManagement/oecd/science-and-technology/the-next-production-revolution_97892 64271036-en\#page, chapter 12.

108 OECD, The Next Production Revolution (n 107) 202.

109 Ernst \& Young Report (n 40) 11.

110 HIS Markit, Asia Investing Heavily in 3D Printing Technology (14 July 2014) at https://technology.ihs.com/506093/important-regional-developments-for3d-printing-technology.

111 ibid.

112 International Data Corporation, Japan 3D Printing Forecast 2017-2021 (August 2017). 
A number of other mid-sized countries have sought to bridge the innovation gap with the leaders in the field. Canada has sought to emulate the US success in innovation with its Innovation Superclusters Initiative $^{113}$ which also includes an Advanced Manufacturing Supercluster. ${ }^{114}$ However, there will be complex issues involved in managing IP associated with such superclusters. ${ }^{115}$ The Canadian government has issued a new National Intellectual Property Policy in 2018 to help boost its innovation policy. ${ }^{116}$

There has also been some experimentation with the use of $3 \mathrm{D}$ printing to help fulfil sustainable development goals. ${ }^{117}$ In respect of access to water, Deakin University researchers have been interested in how 3D printing may address issues in respect of refuse and lack of access to clean water in Pacific island states such as the Solomon Islands. ${ }^{118}$ In the area of health-care, MSF has been experimenting with 3D printing to develop prosthetic devices in its field hospital in Jordan. ${ }^{119}$ The Solar Sinter project has sought to make glass objects out of sand and sunlight. ${ }^{120}$

113 Government of Canada, Innovation Superclusters Initiative (2018) at https://www.canada.ca/en/innovation-science-economic-development/programs/ small-business-financing-growth/innovation-superclusters.html.

114 Government of Canada, 'Canada's new Superclusters' at https://www.ic. gc.ca/eic/site/093.nsf/eng/00008.html.

115 Sean Silcoff, 'Is Ottawa's "Supercluster" Funding Initiative a Superboondoggle in the Making', The Globe and Mail, 16 March 2018 at https:// www.theglobeandmail.com/report-on-business/is-ottawas-supercluster-fundingintiative-a-superboondoggle-in-themaking/article38297014/.

116 Myra Tawfik, 'Why It's So Important for Canadians to Be Able to Leverage Their Intellectual Property', The Globe and Mail (27 April 2018) at https://www.theglobeandmail.com/business/article-why-its-so-important-forcanadians-to-be-able-to-leverage-their/.

117 Thomas Birtchnell and William Hoyle, 3D Printing for Development in the Global South: The 3D4D Challenge (Palgrave Pivot 2014).

118 Kathryn Powley, 'Deakin University 3D Printer to Bring Clean Water to the Pacific and Clean Up Plastic Waste', Herald Sun (25 April 2017) at http://www.heraldsun.com.au/news/victoria/deakin-university-3d-printer-to-bringclean-water-to-the-pacific-and-clean-up-plastic-waste/news-story/8fbf6d239f8c0e a22a6046da6dedf79b.

119 MSF, 'Jordan: A Decade of Healing at MSF's Reconstructive Surgery Hospital' (20 December 2017) at http://www.msf.org/en/article/jordan-decadehealing-msf\%E2\%80\%99s-reconstructive-surgery-hospital.

120 Markus Kayser, 'Solar Sinter Project', Vimeo (21 June 2011) at https:// vimeo.com/25401444. 
Worthy of note is also the debate about the application of 3D printing in South Africa, and the implications for sustainability as well as IP.121 Commenting on the African states, Calestous Juma has reflected that 'the Internet of Things, 3D printing, digital learning, and open source movements provide collaborative opportunities for inclusive innovation'. ${ }^{122} \mathrm{He}$ observed that such technologies need policy modifications and adaptations. 'It is not sufficient that policies are inclusive; their formulation and the design of new technologies also need to include potential beneficiaries.' ${ }^{123}$ Calestous Juma noted that the legal system struggled to keep up with the rise of 3D printing: 'One of the main legal challenges is the potential convergence of digital information and physical objects. ${ }^{124} \mathrm{He}$ contended that the conflicts over IP and 3D printing were often a manifestation of deeper economic tensions: 'What may appear on the surface as being intellectual property concerns may in fact reflect deeper tensions between technological innovation and incumbency.' ${ }^{125}$

Whilst these countries have certainly made a mark in developing 3D printing technologies, it is fair to submit that there has not been as much movement in addressing IP challenges as has been the case with countries such as the UK, the USA and Australia. Of course, the same is not true for Germany - a market leader in developing this technology as well as addressing IP implications as a result of it. However, it should be noted that in considering the UK, the book delves into developments in European law and therefore considers any European Union (EU) legal developments as relevant.

121 Erika Kraemer-Mbula and Chris Armstrong, The Maker Movement in Gauteng Province, South Africa, Open AIR Working Paper, 6 June 2017; and Munyaradzi Makoni, '3D Printing in Africa: Huge Benefit or Big IP Threat?', Intellectual Property Watch, 13 March 2017 at https://www.ip-watch.org/2017/ 03/13/3d-printing-africa-huge-benefit-big-ip-threat/.

122 Calestous Juma, Innovation and Its Enemies: Why People Resist New Technologies (Oxford University Press 2016) 301.

123 ibid. 301. For further insight into the South African additive manufacturing and 3D printing developments, including the rise of the Maker Movement, see Jeremy de Beer, Chris Armstrong, Meika Ellis and Erika Kraemer-Mbula, $A$ Scan of South Africa's Maker Movement, Open AIR Working Paper, 21 December 2017.

124 ibid. 301.

125 ibid. 306. 


\subsection{Response from International Legal Organisations}

There is also a larger interest in how the international legal regime is addressing the rise of 3D printing and additive manufacturing. The World Intellectual Property Organization (WIPO) has conducted empirical research into 3D printing as a breakthrough technology ${ }^{126}$ and through the research noted that in the field of 3D printing, the top patent applicants come from the USA, Germany and Japan. Cathy Jewell of WIPO has noted:

3-D printing raises a number of regulatory challenges including in relation to intellectual property protection. Just as the digitization of creative content has forced change within the creative industries and fuelled tensions around existing copyright law, similar debates are likely to emerge in relation to 3-D printing. Given the global scale of manufacturing, however, the stakes in this debate may be even greater. ${ }^{127}$

Furthermore, the Director-General, Francis Gurry, has highlighted the expansion in the value of the global 3D printing business. ${ }^{128} \mathrm{He}$ has said of new technologies, such as 3D printing, robotics and nanotechnology: 'We need to reinforce the environments that give rise to the breakthrough technologies of tomorrow.' ${ }^{129}$

The World Trade Organization (WTO) has also been interested in how $3 \mathrm{D}$ printing and additive manufacturing may transform world trade. ${ }^{130} \mathrm{~A}$ recent report by the WTO considers whether 3D printing can lead

126 World Intellectual Property Organization (n 101).

127 Cathy Jewell, '3-D Printing and the Future of Stuff', WIPO Magazine (February 2013) at http://www.wipo.int/wipo_magazine/en/2013/02/article_0004. html.

128 Catherine Saez, 'WIPO Demonstrates 3D Printing: Making The Impossible Possible', Intellectual Property Watch, 25 April 2013 at https://www. ip-watch.org/2013/04/25/wipo-demonstrates-3d-printing-making-the-impossiblepossible/; and AFP, '3D Printing Could Herald New Industrial Revolution', The Sydney Morning Herald (28 April 2013) at http://www.smh.com.au/technology/ technology-news/3d-printing-could-herald-new-industrial-revolution-20130428-2 ingp.html.

129 World Intellectual Property Organization, 'Small Group of Countries Drives Innovation in Breakthrough Technologies', Press Release, Geneva (11 November 2015) at http://www.wipo.int/pressroom/en/articles/2015/article_0015. html.

130 World Trade Organization, World Trade Report 2013: Factors Shaping the Future of World Trade, at https://www.wto.org/english/res_e/publications_e/ wtr13_e.htm. 
manufacturing and its supply-chains to return to developed countries through 'in-sourcing'. Finbarr Livesey wonders whether 3D printing and emerging technologies could 'herald another move away from global value chains and a further pressure toward physical deglobalization'. ${ }^{131}$ The National Board of Trade in Sweden has considered some of the regulatory challenges posed by 3D printing. ${ }^{132}$ The Board contends: 'Since 3DP changes how production takes place, where manufacturing is done, and who participates in trade and production, it should also change trade negotiations.' ${ }^{133}$ The Board maintains that 'a clear legal framework is seen as essential, not least in relation to questions like liability and protection of intellectual property rights. ${ }^{134}$ Given how IP has been integrated into multilateral, regional and bilateral trade agreements, there could be complex issues arising in respect of the digital distribution of 3D printing. ${ }^{135}$

The United Nations has also expressed concerns about the misuse of 3D printing. United Nations Secretary-General Ban Ki-Moon told the United Nations Security Council: 'Information and communication technologies, artificial intelligence, 3D printing and synthetic biology will bring profound changes to our everyday lives and benefits to millions of people.' ${ }^{136} \mathrm{He}$ worried, though, that 'their potential for misuse could also bring destruction'. ${ }^{137}$

131 Finbarr Livesey, From Global To Local: The Making of Things and the End of Globalization (Pantheon Books 2017) 60.

132 National Board of Trade (Sweden), Trade Regulation in a 3D Printed World (National Board of Trade 2016) at https://www.kommers.se/Documents/ dokumentarkiv/publikationer/2016/Publ-Trade-Regulation-in-a-3D-Printed-World. pdf.

133 ibid. [3].

134 ibid. [15].

135 The US litigation in ClearCorrect Operating LLC v ITC, 810 F3d 1283 (Fed Cir 2015) provides an early consideration of the relationship between IP, trade and 3D printing.

136 Ban Ki-Moon, 'Addressing Security Council, Secretary-General Calls for Recommitment to Eradicating Weapons of Mass Destruction "Once and For All”, United Nations (23 August 2016) at https://www.un.org/press/en/2016/ sgsm17996.doc.htm.

137 ibid. 


\section{A COMPARATIVE ANALYSIS OF INTELLECTUAL PROPERTY AND 3D PRINTING}

\subsection{The UK, the USA and Australia as Thought Leaders in Intellectual Property and 3D Printing}

As outlined above, whilst it is necessary to understand the importance of the selected jurisdictions in developing 3D printing and AM technologies, it is not the aim of this book to chart the technology. Rather, the aim is to provide a comprehensive overview of the implications for IPR of 3D printing, 3D scanning and additive manufacturing technologies. In this context it is submitted that the UK, US and Australian governments have invested heavily in attempts to identify and unravel the complex issues surrounding IP laws as a result of this technology.

For example, the UKIPO led the way with a commissioned project in 2013 exploring the IP implications of 3D printing, which resulted in the publication of two research reports and an executive summary in 2015, ${ }^{138}$ followed closely by a second commissioned project in 2016, which was completed in October 2018. ${ }^{139}$ In the USA, the United States Patent and Trademark Office (USPTO) has been involved in hosting conferences dedicated to $3 \mathrm{D}$ printing and IP, showing their commitment to the

138 The UKIPO project was led by Professor Dinusha Mendis of Bournemouth University in collaboration with Dr Phil Reeves of Stratasys Consulting and Dr Davide Secchi of Southern University Denmark (formerly Bournemouth University) and resulted in two key reports and an executive summary: Dinusha Mendis and Davide Secchi, A Legal and Empirical Study of 3D Printing Online Platforms and an Analysis of User Behaviour (UK Intellectual Property Office 2015); Phil Reeves and Dinusha Mendis, The Current Status and Impact of $3 D$ Printing within the Industrial Sector: An Analysis of Six Case Studies (UK Intellectual Property Office 2015); Dinusha Mendis, Davide Secchi and Phil Reeves, A Legal and Empirical Study into the Intellectual Property Implications of 3D Printing: An Executive Summary UK Intellectual Property Office 2015). All three reports can be accessed at https://www.gov.uk/government/publications/ 3d-printing-research-reports.

139 A second commissioned project was led by Dr Angela Daly of the Chinese University of Hong Kong (previously of Queensland University of Technology, Brisbane, Australia) and carried out by Thomas Birtchnell, Thierry Rayna, and Ludmila Striukova exploring '3D Printing and IP Futures', https://www.gov.uk/ government/publications/3d-printing-and-intellectual-property-futures?utm_source =Twitter\&utm_medium=social\&utm_campaign=SocialSignIn. The project, which commenced in January 2017 was completed in October 2018. A blog about the project can be accessed at https://3dpipfutures.com/. 
cause. ${ }^{140}$ In the meantime, a number of White Papers have originated from the USA discussing the multifaceted issues surrounding 3D printing, 3D scanning and IP law. ${ }^{141}$ Most recently, IP Australia published a report on the future of IP law in Australia, which discusses 3D printing as one of the technologies to 'monitor' as it has the 'potential to rapidly transform business and policy environments'. ${ }^{142}$

In this context, it seemed justifiable to delve deep into the three jurisdictions which have already established themselves as market leaders not only in the field of 3D printing and additive manufacturing technologies, but also as thought leaders in addressing the implications for IP laws as a result of $3 \mathrm{D}$ printing.

Furthermore, like many technologies, 3D printing and its associated elements such as online platforms and CAD files, are universal in their reach, as discussed in a number of upcoming chapters. Yet the law is territorial. Mendis, Nielsen, Nicol and Li comment: 'This anomaly reflected through the universality of the technology coupled together with ever-growing distribution networks may ultimately lead to the law being shaped in different legal regimes, in different ways, resulting in a lack of certainty for creators and users and incompatibility of rights and working conditions across common technological systems.' ${ }^{143}$ This is because 3D printing and 3D scanning touch on all aspects of IP, unlike the issues which existed in the entertainment industry, which revolved mostly around copyright law.

Whilst a number of research papers, legal commentaries and commissioned projects have considered the issues from the point of view of the three selected jurisdictions of the UK, the USA and Australia, the IP

140 USPTO IP and 3D Printing Conference (28 June 2016) at https://www. uspto.gov/learning-and-resources/ip-policy/uspto-ip-and-3d-printing-conference.

141 Michael Weinberg, It Will Be Awesome If They Don't Screw It Up: 3D Printing, Intellectual Property and the Fight Over the Next Great Disruptive Technology (Public Knowledge November 2010); Michael Weinberg, What's the Deal with Copyright and 3D Printing (Public Knowledge November 2013); Michael Weinberg, Three Steps for Licensing your 3D Printed Stuff (Public Knowledge November 2015); Christopher Healy and others, 3D Printing of Manufactured Goods: An Updated Analysis (Reed Smith December 2016).

142 IP Australia, IP Australia and the Future of Intellectual Property: Megatrends, Scenarios and their Strategic Implications (July 2017).

143 Dinusha Mendis, Jane Nielsen, Dianne Nicol and Phoebe Li, 'The Co-Existence of Copyright and Patent Laws to Protect Innovation: A Case Study of 3D Printing in UK and Australian Law' in Roger Brownsword, Eloise Scotford and Karen Yeung (eds), The Oxford Handbook of Law, Regulation and Technology (Oxford University Press 2017) chapter 19. 
landscape remains fragmented in this field. This is due to the fact that there is a gap and a lack of a single, comprehensive text covering all aspects of IP from the viewpoint of these three jurisdictions. There are some excellent books which touch upon IP issues although they do not consider the multitude of issues canvassed in this collection in a systematic, detailed and comparative manner. ${ }^{144}$ Therefore, it is imperative, at this stage, to provide much-needed clarification on the implications for IPRs wrought by 3D printing and 3D scanning, whilst the issues remain speculative and prior to the contemplation of legislation in this field. In this context, it is hoped that the book will provide clarity on 3D printing, 3D scanning and IP law from the perspective of the UK, the USA and Australia, thereby informing policy at a national and global level.

\subsection{A View on 3D Printing and Intellectual Property Law from Three Common Law Jurisdictions Spanning Three Continents}

Another reason for focusing on the UK, the USA and Australia is that they share a common law tradition. Apart from providing a shared platform for purposes of reviewing the law, common law jurisdictions also allow the law to develop incrementally, without the need to wait for statutory action. As such, this legal tradition has the benefit of informing and shaping policy ahead of legislative intervention. For example, respective case law on the boundaries between copyright law and design law drawn from the UK, the USA and Australia, such as Lucasfilm Ltd \& Others $v$ Ainsworth and Another, ${ }^{145}$ Star Athletica LLC $v$ Varsity Brands Inc et al. ${ }^{146}$ and Seafolly Pty Limited $v$ Fewstone Pty Ltd, ${ }^{147}$ have informed IP laws surrounding 3D printing. Controversies over 3D printing projects such as the Iron Throne and Left Shark have raised questions about the nature and scope of trade mark law. The patent litigation in the case of ClearCorrect Operating LLC $v$ International Trade Commission has raised larger questions about IP, trade, digital

144 See van den Berg, van der Hof and Kosta (eds) (n 34); Angela Daly, Socio-Legal Aspects of the 3D Printing Revolution (Palgrave Macmillan 2016); Ballardini, Norrgard and Partanen (n 102).

145 Lucasfilm Ltd \& Others v Ainsworth and Another [2011] 3 WLR 487.

146 Star Athletica LLC v Varsity Brands Inc et al 580 U.S. (2017).

147 Seafolly Pty Limited v Fewstone Pty Ltd [2014] FCA 321 (1 April 2014). 
distribution and 3D printing. ${ }^{148}$ The legal disputes over 3D printing of guns in the USA are being considered in a range of other jurisdictions. ${ }^{149}$ In this context, it is accurate to state that '... judge made law is not only a source of law, but, an important source of law'.150

As Lord Goff so eloquently pointed out, common law provides 'a base for future operations as the law develops from case-to-case - and occasionally backwards if we are modest enough to recognise that perhaps they have gone too far'. ${ }^{151}$ Furthermore, the ability of the common law to adapt itself to the differing circumstances of the countries in which it has taken root is a great strength of the common law system, ${ }^{152}$ paving the way for common law countries to learn from each other - as intended by this book. Therefore, by positioning the focus firmly on three common law jurisdictions drawn from three continents, this book aims to inform national and international policy by providing a starting point for untangling the web of complex cross-border IP issues which have arisen as a result of $3 \mathrm{D}$ printing.

\section{OVERVIEW AND LAYOUT OF THE BOOK}

Before embarking on an analysis of the IP rights in each jurisdiction, the first chapter in the book presents Mark Lemley's discussion of 'IP in a World Without Scarcity'. This discussion is intended to act as a theoretical superstructure for the collection and serves as a springboard for the chapters which will follow.

Thereafter the book moves to an in-depth consideration of the various IP rights - i.e., copyright, design law/design patent, trademarks, trade dress and patents - drawn from the UK, the USA and Australia. The

148 ClearCorrect Operating, LLC v International Trade Commission 810 F. 3d 1283 (2015); and ClearCorrect Operating, LLC $v$ International Trade Commission F.3d 1334 (2016).

149 Cody Wilson, Come and Take It: The Gun Printer's Guide to Thinking Free (Gallery Books 2016). See Defense Distributed v United States Department of State 838 F.3d 451 (2016). State of Washington, et al. v United States Department of State, et al. (2018) Case 2:18-cv-0115-RSL, 2018 WL 3629632; and State of Washington, et al. v United States Department of State, et al. (2018) 318 F. Supp. 3d 1247.

150 Lord Goff, 'Future of the Common Law' (1997) 46 International and Comparative Law Quarterly 745; see also, Lord Justice Bingham of Cornhill, 'The Future of Common Law' [1999] Civil Justice Quarterly 209.

151 Lord Goff (n 150) 753.

152 Invercargill City Council v Hamilton [1996] AC 624, 640. 
book is presented in three main sections, divided according to these three jurisdictions.

The commentary on the implications for IP law as a result of 3D printing, 3D scanning and additive manufacturing technologies in each jurisdiction is punctuated with a chapter at the end of each jurisdictional section that considers the regulation of new and emerging and future technologies and its implications for the legal landscape. As such, at the end of the IP coverage on each jurisdiction, the book looks beyond 3D printing to consider legal, ethical, contractual and regulatory implications for new and emerging technologies.

By bringing together experts in the field of IP rights, the book provides the most comprehensive coverage to date on the implications for IP and 3D printing in the UK, the USA and Australia. The book also highlights opportunities and challenges for the regulation of 3D printing and other additive manufacturing technologies. 